Int. J. Dev. Biol. 48: 687-694 (2004)

doi: $10.1387 / \mathrm{ijdb} .041857 \mathrm{rt}$

\title{
The extracellular matrix in development and regeneration
}

\author{
An interview with Elizabeth D. Hay
}

Betty Hay was born in Melbourne, Florida and raised there until her father enlisted as an army physician during World War II. Her family moved to Mississippi and to Kansas and then returned to Florida when her father left for military duty in the Philippines. In1944, Betty entered Smith College where her emerging interests in biology were significantly accelerated by a freshman biology course with Professor S. Meryl Rose, who became her scientific mentor. She worked with Rose on amphibian limb regeneration at Smith and in the summers at the Marine Biological Laboratory in Woods Hole. Upon graduation Betty entered Johns Hopkins Medical School and graduated in the Class of 1952. During medical school Betty was able to continue interacting with Florence and Meryl Rose at Woods Hole (Fig. 1B). Upon graduating from Hopkins and interning in medicine, Betty joined the Anatomy Department at Hopkins, discovered the emerging field of electron microscopy and began to interact with George Palade and Keith Porter at Rockefeller and with Don Fawcett at Cornell Medical College. She moved to Fawcett's Anatomy Department at Cornell in 1957 and thus was in New York at the time when cell biology opened up. In 1960, Betty moved to Harvard Medical School with Fawcett and there rose through the ranks to become the Louise Foote Pfeiffer Professor of Embryology in 1964 (Fig. $1 \mathrm{~A})$ and Chair of the Department of Anatomy in 1975. Betty has been President of the American Society for Cell Biology, the Society for Developmental Biology, the American Association of

\author{
ROBERT L. TRELSTAD*
}

Child Health Institute, Robert Wood Johnson Medical School, New Brunswick, New Jersey, USA

Anatomists and she has won over twenty national and international awards including the E.B. Wilson Award in cell biology (Fig. 3) and the E G. Conklin Award in developmental biology. She is a member of the National Academy of Sciences and has served on countless national and international committees. Betty lives in Weston, Massachusetts, with multiple cats and surrounded by woods filled with mushrooms about which she is an expert in harvesting, cooking and eating.

\section{Given your years in the South, how did you come to go to Smith College?}

That's an interesting question. I was geared to get into a good college having been raised in a small Florida town that had a lousy High School. I was self motivated and very attracted to science. The reason I picked Smith was because there was a very dear family living over at the beach that my brother and I and my sister played with all the time. Their name was Gordon and my friend's mother had gone to Smith and so I applied to Smith and I got in. But that was the only reason that I chose it. I was already very interested in biology, but the High School biology teacher also was the athletic coach and I didn't pick up much from him. I hid my interest in science from him and the other students. I did a lot of reading on my own. It was not very fashionable to be a study wart at that time. Ironically, I think I managed to get into Smith because

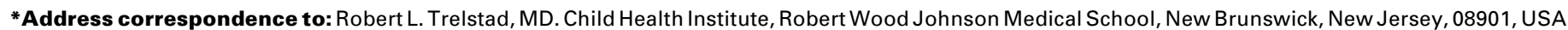
Fax: +1-732-235-9333. email: trelstad@umdnj.edu
} 

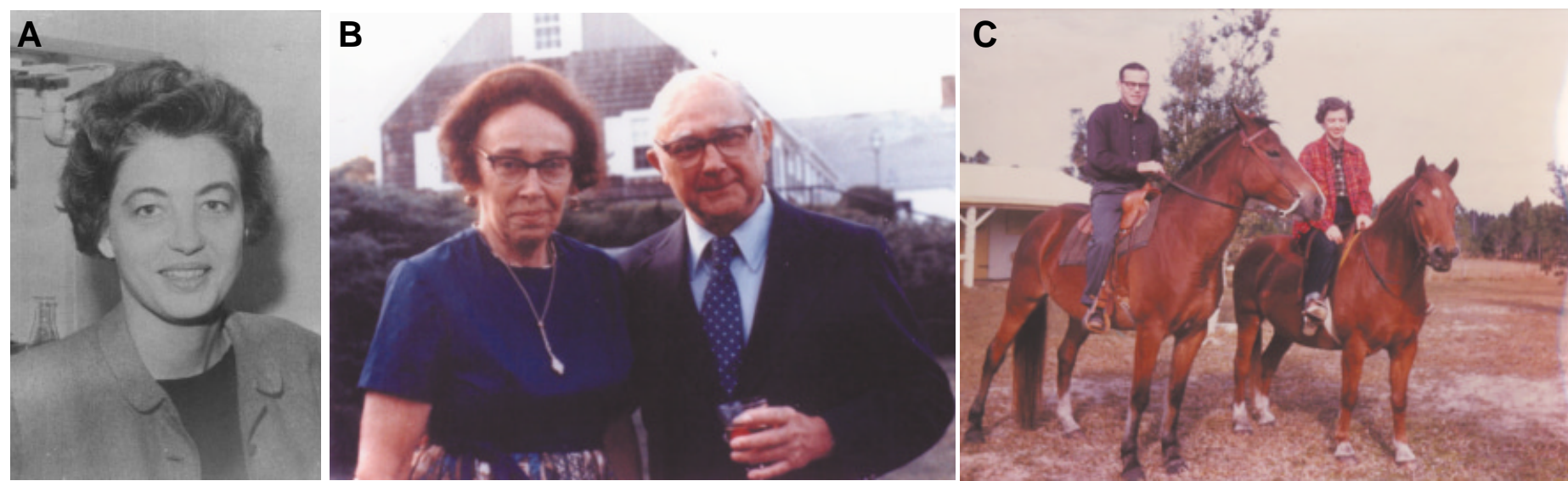

Fig. 1. Extracts from the earlier days of Dr. Hay. (A) Dr. Hay at Harvard Medical School (ca. 1964). (B) Florence and Meryl Rose in Woods Hole, with whom Dr. Hay interacted during medical school. (C) Riding horses with brother Jack in Florida.

of the science I learned on my own. I had to take a College Entrance Exam before I was accepted. I didn't do too well on that exam except for the science. When I got to Smith I had to take remedial courses in English. Soon after I got to Smith I took a freshman course in Anatomy and Physiology taught by Meryl Rose. Initially I thought I'd like to be an artist. I drew cartoons for my High School newspaper in Melbourne and while I thought I might pursue art at Smith, I dropped the idea because I was so taken with the biology course taught by Rose. It was just marvelous. So from my freshman year on I became a biology major. My exposure to Meryl Rose was a big feature in my life. Meryl at that time was working on regeneration and by the end of my first year at Smith I was also studying regeneration.

Can we go back to the science interests that you developed before Smith again? You obviously had a very inquisitive mind from the get-go. The nice thing about science is that you can ask questions and get answers. But was there something in particular in Florida that captured your scientific interest. Was it the stars, the seasons, the organisms that you dissected?

I don't remember being interested in astronomy. Biological structure was just something that clicked with me. I later became very interested in math, but not in High School. In the first summer when I was at college, I taught horse back riding at Camp Aloha in Fairfield, Vermont and whenever the little girls would bring in a dead squirrel or whatnot, l'd dissect it for everybody and show them where the stomach was and so on. And I couldn't get enough of this desire to see what was inside various animals.

\section{Where did you learn how to ride horses?}

My twin brother, Jack and I in Florida shared a horse we received for our $12^{\text {th }}$ birthday and both Jack and I loved riding (Fig. 1C). Jack wasn't particularly interested in science, but he was a magnificent musician. My father wanted him to be a doctor and was not all that supportive of his becoming a musician. He became a clinical psychologist and so did his daughter and our sister Kitty's daughter. There is a lot of horse riding and cattle raising in Florida even now. It's almost like Texas. Jack and I adored horses.

\section{Tell me a bit more about your parents, Isaac Hay and Lucille Elizabeth Hay}

My father was from Chicago and he went to medical school at Northwestern. He was doing an internship in St. Augustine, Florida on the railroad. The 'Flagler' Railroad had hospitals up and down the east coast of Florida. My father met my mother, who was born and raised in St. Augustine, Florida, when he was interning with the railroad. After they got married my father decided he wanted to start a private hospital in Melbourne, Florida. So in 1929, when Jack and I were two years old, we moved from St. Augustine to Melbourne where my father, who was a general practioner, started the hospital. They were just starting the hospital and had rented a building and acquired five beds when the bottom dropped out of the stock market. After the crash they didn't have enough money to buy food for the patients and they had to charge it all. But they had a very kind grocer who helped them get through the crisis. Fortunately, after about 4 or 5 years, Brevard county was persuaded to take over the hospital and they built a new one. My father was never too good at timing his financial enterprises. Florida had a big boom in the 20's, then crashed in the 30's. In 1929 you could buy up land for the taxes and instead of opening hospitals, later on sell it to become a millionaire. My father, however, is still known as a pioneer in Melbourne for having established the first hospital.

\section{Before we leave your father, tell me about your experi- ences during the World War II and your moves to Mississippi and Kansas}

My father was very, very patriotic and after Pearl Harbor he immediately tried to enlist in the Navy Medical Corp and they wouldn't take him because his pulse was too fast. It took him 3 or 4 months of trying and, probably with help of a drug that could keep his pulse down, he got admitted to the Army Medical Corp. In the spring of 1942 he was shipped off to Biloxi, Mississippi, where there was a base called Keesler Field. My mother chose to go with him and that was not good for us kids because the schools in Missis- 
sippi were worse than in Melbourne. They were just unbelieveable. We were there almost a year and then my father was sent to a base in Kansas called Fort Hayes. I loved Kansas. The schools in Hayes were super. I took a course in airplane mechanics and was about to learn to fly at the age of 16 when my father was shipped off to the Phillipines and we came home to Florida. My father was in the Phillipines for about three years and he earned many medals for saving soldiers' lives under fire with his superb surgery.

\section{Before we leave your family, tell me about the endow- ment at Hopkins in honor of your mother and father.}

I intend to leave most of what I have to endow a chair called the Isaac and Lucille Hay Professor of Embryology at the Johns Hopkins School of Medicine. My mother, Lucille, was my most favorite person in the world and supported me and the family with all her heart and soul. So they both need to be honored.

\section{Let's go back to Meryl Rose and your freshman biology course at Smith.}

This was a wonderful course for somebody like me. It wasn't just a comparative anatomy course where you classified the animals. The lectures were on the function of things and the slide collection was on a par with what we have here at Harvard in histology. It was a very elite course looking at real slides and drawing them, since I always liked to draw. But at Smith I stopped trying to draw people with water color and charcoal. Those are the two methods that you should never start out with. In any case I also had a wonderful time drawing pictures of slides and dissected animals. These experiences cemented my desires to go on in biology. At the same time, I became intensely active in some of the many extracurricular activities at Smith. I ran the weekly newspaper, was house president and a member of the riding team.

\section{What was the central question that Rose was asking at Smith that dealt with limb regeneration?}

Rose was interested in the induction of limb regeneration in animals that were not able to regenerate their limbs. So he had a large frog colony and he would amputate their limbs and stick the animal's limb in salt water to try to irritate it, add various chemicals and that sort of thing. I never did that. The project that he gave me to work on was to prove that the epidermis dedifferentiated and give rise to part of the regenerate. Well, I ended up not proving that by tracing cells, using transplants of triploid tissue. Subsequently, with my student Don Fischman, I used tritiated thymidine to follow the epidermis and other limb tissues by autoradiography and we also came up negative for the epidermis. I got very interested in the cellular basis of regeneration. Meryl's major contribution was in finding ways to stimulate lost powers of regeneration in animals.

You might ask why I chose not to get a PhD. In that my father was overseas from 1942 to 1945 and I was at Smith from 1944 to 1948. I had little to no interaction with him in my career decisions. Meryl Rose urged me to get an MD. He told me 'you're not going to get any good jobs unless you have an MD. If you just get a PhD you're going to get stuck in a girl's college like Smith for the rest of your life'. So, since I almost always did what Meryl said, I applied to Hopkins and off I went. I didn't apply to Harvard. They had just starting taking women in 1945. It was 1948 and I was told they didn't even have enough female bathroom facilities yet.

There was no question about my choosing Hopkins. I was from Florida and Hopkins was the most famous hospital for the south. It was a good choice. And I want you to know, right now, that they are still ranked equal to or higher than Harvard in their national standing in medicine. So there. That's Hopkins. I went to it when I did because it was the only school l'd heard of. Also it had accepted women from its inception and treated them well.

\section{So Meryl Rose launched you into research in regenera- tion that you continued in medical school?}

That's right, so during the whole time I was in medical school, I worked with Rose during the summers at Woods Hole. The chair of the Anatomy Department at Hopkins, Dr. Allan Grafflin, was gung-ho to promote women's careers. He could see that I was very turned on by anatomy because I really got into those dissections. And I was wonderful at histology. I just loved histology and he used to come by and look at the slides and try to find something that I couldn't identify, but l'd always get it right. Grafflin gave me a lab in the Anatomy Department before the end of the first year and I continued to do research on regeneration.

What saved me was that in the summers I went to Meryl and Florence Rose's laboratory in Woods Hole. Meryl had one of the first NIH grants. The Roses brought people from the University of Illinios, where he had moved to and there were four or five of us

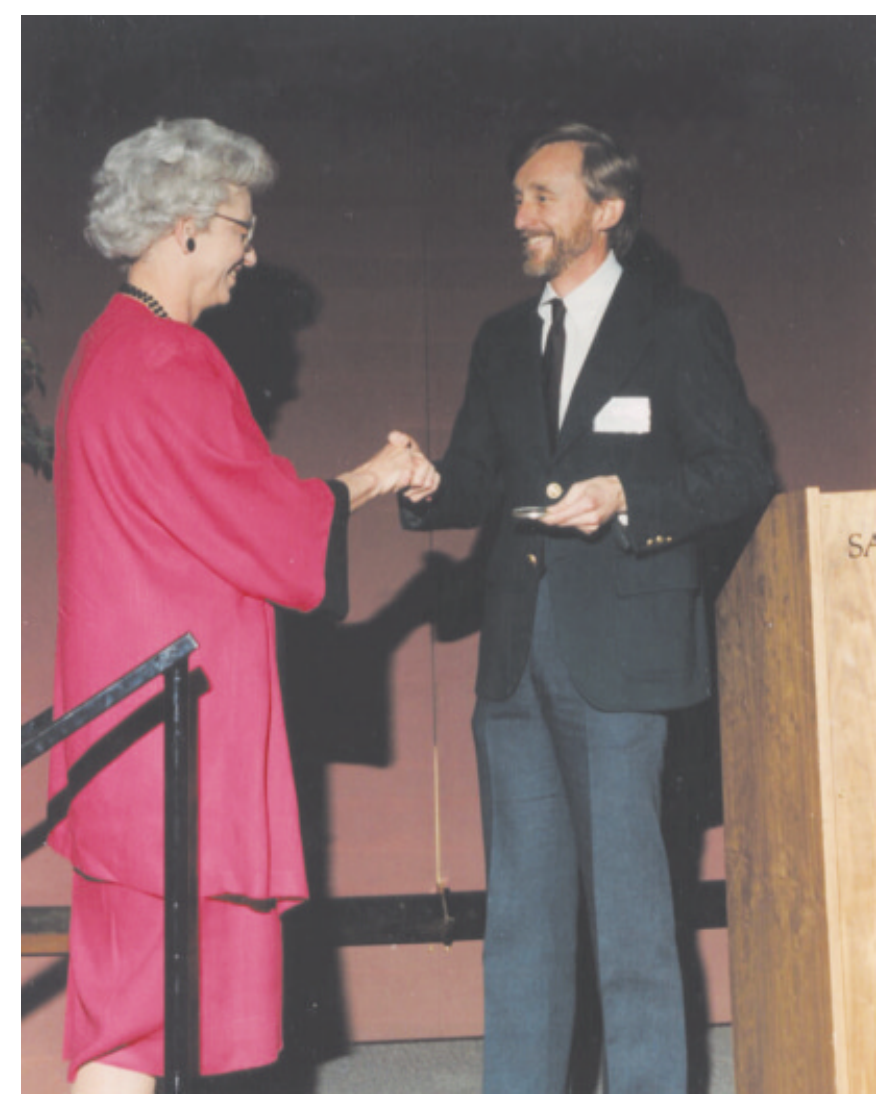

Fig. 2. Receiving the E.B. Wilson medal from $A S C B$ President Tom Pollard. 
working in the lab and we'd go out to the house almost every evening and sometimes have dinner with them and other times we'd just come by late and we would play games, or we would just all sit around talking science. And the interaction with Florence and Meryl Rose was just so profound it influenced the careeers of all of us, such as Tweedell, Rafferty and Glade. The kind of attention that that husband-wife team gave to the students who were working with them was exceptional; it could only have been done really in Woods Hole because you wouldn't be able to have that informal a relation on a continuous basis in a city.

\section{After receiving your MD in 1952 how did you pursue your formal research training and career?}

I interned at Hopkins from 1952 to 53. In 1953 Allan Grafflin offered me a position as an Instructor in Anatomy at Hopkins. And I was offered absolutely no other positions anyplace else. I never did any work with Allan Grafflin. He was kind of a neurotic fellow. Although the head of the Anatomy department he failed to notice the creation of electron microscopy. I went to a meeting in 1954 in Atlantic City with some friends just to go to Atlantic City. And my gosh, Keith Porter gave a symposium lecture on the fine structure of the basophilic substance of the cytoplasm. And, of course, it was composed of Palade granules (ribosomes) and the endoplasmic reticulum that $P$ alade and Porter had just described. And I had been teaching histology to Hopkins medical students since 1953, so I was very interested in the basophilic substance of the cytoplasm. But, boy, I just couldn't believe that this was the structure.

And I came back and, wow, from then on it was electron microscopy for me. I went looking for electron microscopes at Hopkins on my own. I didn't get any help from Grafflin, but I found out that Fred Bang had one over in the School of Public Health. Bang was not a cell biologist by any stretch, but he was a really nice person and he let me use his whole facility. He had the only transmission electron microscope (TEM) at Hopkins in 1954.

\section{Why did Fred Bang have an Electron Microscope in the School of Public Health at Hopkins?}

Well, I don't remember at all what he was doing with it. He went to Wood's Hole every summer and he taught courses on parasites of different types. He had several students and was personally responsible for arranging TEM seminars and brought George Palade down often so that we could talk to him.

I was lucky enough to be befriended by Fred Bang, but what I couldn't resolve was why, oh why, were my pictures so awful? They were not as pretty as the Porter, Palade and Fawcett pictures of that era nor did they contain as much information. So I would get on a train and go up to Rockefeller where Keith Porter and George Palade would both see me. This was before Fawcett's move to Cornell from Harvard. I continued my episodic trips to New York after Fawcett arrived there, hauling all my pictures up there and showing them to these poor trapped professors. Here was this strange female travelling up the coast once a month from Baltimore to show them her lousy electron micrographs and they tried to help me find out what I was doing wrong. As I reel this off, I wonder what George and Keith were thinking when the secretary announced that 'that lady was here again'. But they were very nice people and didn't run and hide. So it soon became apparent to me that I had to leave Hopkins and go to New York. At that point Grafflin had resigned and I applied to Don Fawcett, who had moved to New York City in 1956 to chair Cornell's Anatomy Department. And Grafflin, who had been at Harvard with Fawcett, gave me a strong recommendation. So Fawcett hired me to run his Histology course and I arrived there in 1957.

\section{Betty, did you ask Fawcett for a job or did he offer you a job?}

I asked him for a job. The first TEM job I asked for was when I asked George Palade to take me as a fellow. George at that point and Keith were working very closely together so if you asked one you were asking the other. And they honestly were filled up. You could imagine the demand they were in in the mid to late 1950's because they were at the top of the field and Fawcett was one of their trainees, probably their best one. I was crushed, but there was no way they could take me if they didn't have any room. When Fawcett arrived I would go to see him too on these train trips up from Baltimore. I became an aggressive little soul. So I applied to Fawcett and Grafflin gave me a recommendation. That's how I got the job. And he didn't care a hoot if I was a female. Anyway I got it. I left Hopkins to get into electron microscopy. Nothing could have kept me from going into TEM. Grafflin and Fawcett were on Wislocki's faculty at Harvard in the 1940's and in 1963 weren't you the first George B. Wislocki Fellow in Anatomy at Harvard Medical School?

\section{Yes and I had the great pleasure of spending a year with you in the lab. So how did things progress at Cornell?}

In that I had worked on the problem of limb regeneration for ten years, when I came to Cornell to learn electron microscopy the first thing I tackled was fine structure of the regenerating limb. I was soon able to show by TEM that the blastema that formed on the amputated surface of the amphibian limb consisted of uniform cells that were undifferentiated in appearance. They had lost vestiges of myofibrils and other markers of their previous state of differentiation. I showed by TEM, the stages in the loss of myofibrils by differentiated muscle cells and confirmed light micoscope observations by Thornton that formed limb tissues gave rise to the undifferentiated blastema cells. Soon, I was invited by the Growth Society to present these results at their annual symposium. My conclusion was that differentiated somatic cells of the amphibian limb (muscle cells, cartilage cells) retained enough developmental potency to completely account for regeneration of a perfect limb. In todays' terminology, they would be called stem cells. (Hay, 1962). When I got settled at Cornell I worked with a medical student, Don Fischman and we traced the blastema cells with tritiated thymidine and we followed the cells that labeled with thymidine and found that epidermis did not enter the blastema. It eventually sloughed off. We did a very thorough study of the dynamics of the blastema and showed, without question, that it was the formed internal tissues, not the epidermis and not reserve cells, that gave rise to the regenerating limb. The tissues that contributed the regeneration cells were already differentiated. The developmental potency of the muscle cells has recently been elegantly confirmed by Jeremy Brockes. 
Don Fischman was an excellent student. He was very patient with this autoradiography, which was very new, having just been introduced by Leblond. We were able to follow the cells and we published a very nice paper in 1961. (Hay and Fischman, 1961).

\section{Didn't you and Don Fischman showed that circulating mono- cytes fused to form osteo- clasts?}

Yes, our autoradiography observations on regenerating limbs were the first to prove that mononuclear blood cells are the source of osteoclasts. Many of the people up here at Harvard where I was teaching it, Mel Glimcher for example, said 'well, no, that isn't so maybe salamanders did it that way, but not others...'. That really angered me, but Don Walker, who I taught with at Hopkins in the mid 1950's, already had the idea that

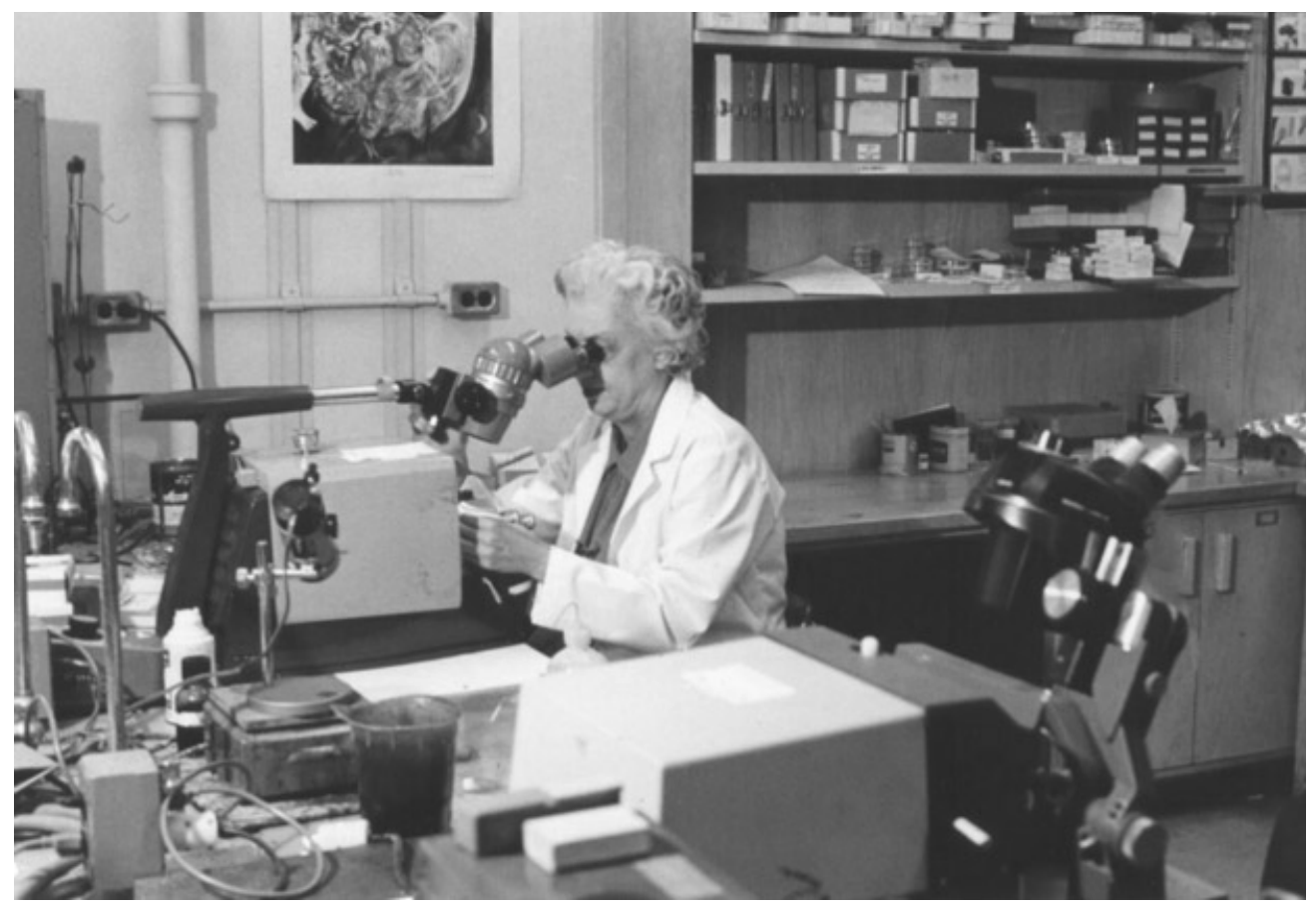

Fig. 3. Sectioning is where the action is. Dr. Hay doing her own sectioning in her laboratory.

circulating monocytes gave rise to osteoclasts and he had developed a treatment for osteoclast dysfuntion that involved transfusion. He was really thrilled with our findings, salamander or not. We looked at the limbs and saw that when silver grains were over the nuclei of mononuclear leukocytes, the osteoclasts always had labelled nuclei. The only place they could get labelled nuclei were from monocytes. So we labelled the blood specifically and showed that was where the osteoclasts came from. The fact that we both were obsessive observers let us get something out of the experiments on the limbs that we hadn't planned to get at all (Fischman and Hay, 1962).

\section{That paper doesn't have the citation index it deserves.}

Well that's probably true.

\section{Tell me more about the Cornell years 1957 to 1960.}

I got an apartment right next to the school so I only had to walk one block to get to work. And I worked very hard. I was in the lab all the time. I worked on regenerating Ambystoma larvae limbs in the TEM. They were just the right size so a section of a limb could fit on one grid. So you could get oriented for the whole grid. In particular, I was trying to find out what Fawcett was doing to prepare his electron micrographs, that I wasn't doing. He still was getting the best pictures of anyone in the deparment. Susumo Ito and Jean-Paul Revel were both there as post-doctoral fellows at that time. I presume they were there for the same reason. What turned out to be the case and this is true for Keith Porter and George Palade to some extent. When they would collect the grids and look at them in the TEM and go through the group they had cut that day, they would throw almost all of them out and only keep the ones that were really pretty. And they would never take pictures of cells that weren't pretty by the best definition at that time. They did all of their own sectioning, of course. To this day, I do my own sectioning (Fig. 3) and throw almost all ugly grids away.

So that it was entirely a matter of selection that I had moved to New York city to learn! Those people were looking for cells that were pretty. They would never take a picture of a cell if it wasn't pretty. That's a philosophy that only a very patient person can develop. Most people would not do that. The rest of us were snapping pictures the minute we sat down. Later on, diamond knives and lead stains were a great help to us commoners.

Obviously there were many other benefits from the move to Fawcett's Department. One was to get in with the group that was doing arguably the best work in the field at that time. It was very exciting and Fawcett brought that excitement with him back to Harvard in 1960. I'm sure you felt that when you were working here as a medical student and during your year off. People were coming through that you'd heard about and were dying to meet. When I was at Hopkins I was isolated in a little pocket.

\section{Who were some of your colleagues at Cornell?}

Jean-Paul Revel (Fig. 4A) got his PhD in the Department of Biochemistry with Eric Ball at Harvard and came with Don Fawcett to Cornell. I don't think Susumu Ito was at Harvard before he came to Cornell as a postdoctoral fellow. Jean-Paul must have interacted with Don at HMS in the early 50's because many people at that time were getting interested in electron microscopy. JeanPaul came down to Cornell as a post-doctoral fellow so he could learn EM and work with Don at Cornell. In 1960, both Sus and Jean-Paul joined the faculty at Harvard and eventually both became professors. Other people at Cornell that moved to Harvard with Don were Kent Christiansen (Fig. 4B) and Mario Burgos. There were many others who came to study TEM at Cornell. It was a very exciting time and the excitement moved with us to Harvard. 

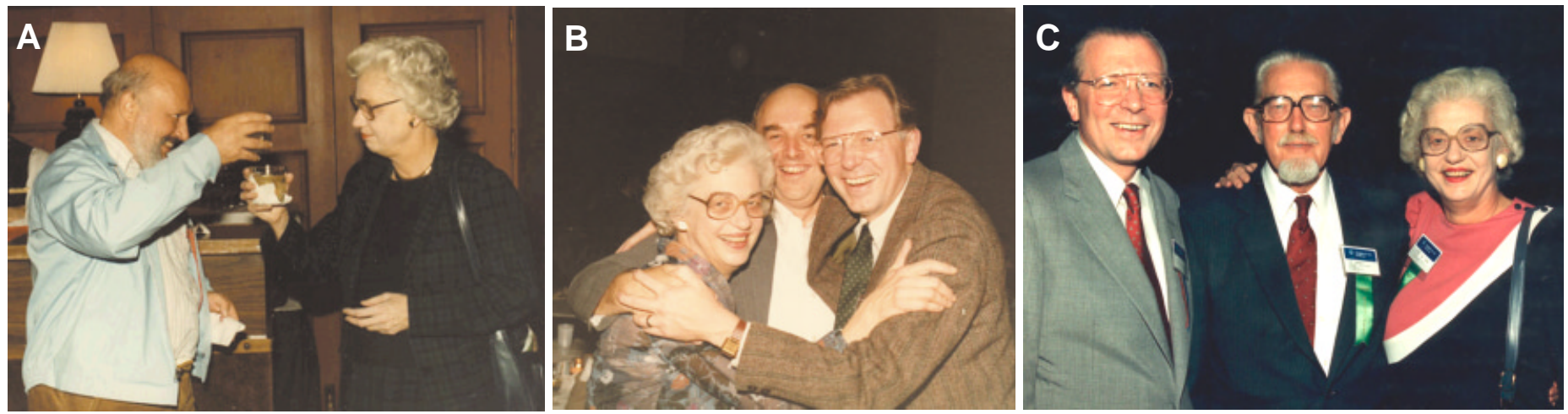

Fig. 4. Dr. Hay participating in ASCB events. (A) Celebrating with Jean-Paul Revel. (B) With Kent Christiansen (middle) and Robert Trelstad at an ASCB reunion. (C) Dr. Hay with ASCB officers Trelstad (left) and Fawcett (middle).

\section{Who else at the Rockefeller do you remember at that time?}

George Palade and Albert Claude were interacting at that time. Claude was sort of a biochemist and he got the Nobel Prize along with George because he was credited with supplying the ideas for examining cell fractions by TEM. Palade was already examining cell fractions when I was at Hopkins and we couldn't wait to hear what he had to say about the composition of this or that cell structure whenever he came down to Baltimore to give a seminar. He defined the mitochondrial fraction enzymes and all this was such a totally new way of looking at the cell, it was amazing.

In 1969 you and Revel published a monograph on the cornea at Harvard. Where did the cornea interest come from?

The autoradiography I was doing at Cornell attracted JeanPaul's interest and before we both left for Harvard, we had begun to collaborate on a project to extend autoradiography to the TEM level. We were doing autoradiography on some regenerating limbs with tritiated proline because we wanted to know if we could identify the emulsion at the EM level. And sure enough we could see silver grains very well above cartilage cells that were making collagen. Such collagen would be heavily labeled, after taking up the tritiated proline and we noticed in those limbs, not only was the cartilage really labeled, but so was the epidermis, which sits on top of an acellular collagenous dermis. We postulated that the epidermis was making collagen. When we did the autoradiography, we found all of the label in the epidermis swept down into the acellular stroma. And the silver grains in the emulsion could be seen in the TEM to sit right on top of collagen fibrils. So we published a paper for the Paul Weiss memorial volume of Developmental Biology stating that the epidermis most likely was making collagen (Hay and Revel, 1963).

\section{I remember the conclusion that epithelia produced col-} lagen caused quite a stir.

Jerry Gross was one of our strongest critics. He argued that the claim by Revel and me that epidermis produced collagen could not be proved by autoradiography and just wasn't possible anyway.
I remember being party to hallway conversations with you and Jerry on this subject more than once. I think the issue in retrospect is not the details, but that mother nature has things in a certain order and if we don't agree on what that order is, we can clarify the disagreement if we work hard enough and ask the right questions.

This argument drove Jean-Paul and me to try to culture the epithelium to show it was producing native collagen. Neither one of us was very good at culturing and I was lucky enough to meet Jim Dodson in 1965 when I went over to Honor Fell's lab one summer and he came over and he was my first post-doc. And he, of course, was very good at culturing and without any problem at all he isolated and grew up the epithelium. We decided to use avian corneal epithelium instead of salamander epidermis because it was sterile and produced exactly the same kind of orthogonal grid of collagen. We set it up on lens capsule, an ECM which Dodson was responsible for introducing as a substratum and in no time at all we had beautiful cultures of the epithelium secreting collagen onto the lens capsule, whereas without the ECM substratum, the epithelium secreted nothing. So the epithelium produced a gorgeous orthogonal collagen stroma on top of lens capsule. l'll never forget Jim Dodson running down to MGH at once to show Jerry Gross the micrographs. Jerry pulled out from his collection of reprints a paper in which he said that epithelium can make collagen and that was in the earthworm. So he gave Dodson a copy of this paper to bring back to me to show me that he knew it all along. Jerry has stimulated a lot of people to do a lot of things.

The controversy Jerry stimulated about whether or not epithelium could secrete collagen drove Jean-Paul and me to look at birds instead of salamanders for more examples of epithelium secreting collagen. The avian cornea proved to be fascinating, not only in lavishly producing a collagenous stroma without fibroblasts, but also in the details of its ontogeny. The 144 page mongraph Revel and I published in 1969 entitled "The fine structure of the developing avian cornea", stimulated so much research by others that I wrote another review later to summarize the field (Hay, 1980). Quite appropriately, much of this follow up research on the mechanisms of corneal development was done in Jerry's lab by you and Toole.

Steve Meier joined our lab as a post-doc at about this time and with Meier's superb talent in the lab we were able to do a large number of experiments to see what effects extracellular matrix of 
different kinds... at that point we were using cartilage collagen and dermis collagen... had on epithelial cell growth or on their differentiation. That was about 1974 and that is when our lab was getting known for promoting the new idea that ECM interacted with cells. Steve Meier was a very important person in developing the concept of cell-matrix interaction. We ended up culturing corneal apithelium on all types of ECM (Meier and Hay, 1974). Today, a whole battery of cell receptors for ECM called integrins has been isolated, but early on in our lab another postdoc, Steve Sugrue, was the first to show ECM binding sites on corneal epithelium (Sugrue and Hay, 1986).

Those studies have been a major foundation of extracellular matrix and its roles in biology and have set a vector. The story is not complete and has become quite complex. The issue of cell matrix interactions is now a hot topic. Lets talk briefly about Epithelial-Mesenchymal Transformations

In a sense, talking about mesenchyme brings us back to the beginning of life. Your professional life, that is. In the 1960's at Harvard, the brightest of the medical students were flocking to the TEM labs in the Anatomy Department, to do research. And you were one of them. Jean-Paul had developed an interest in types of junctions on embryonic cells and we decided to do a TEM study of the primitive streak with you to see what the earliest embryonic contacts were. Epithelial mesenchymal transformation (EMT) occurs from the overlying ectoderm and the migrating mesenchymal cells make many contacts as they move along. You were particularly intrigued by the polarity of the mesenchymal cells as I recall (Trelstad, Hay and Revel, 1967).

Gary Greenburg entered the lab as a graduate student years later. You were on his thesis committee as I remember. He had been a lab technician with Gospodoritz for a long time and he did a lab rotation with me because he'd never seen an embryo. So I set up some 48 hour chick embryos. If you can't fall in love with a 48 hour chick embryo, you're not ready for embryology. I had him cut out the tissues, somites, neural tube, that were making mesenchymal cells. He then put them into collagen gels and see if they'd make mesenchyme and they did like crazy. Gary had been a technician and thought he needed a control, so he decided to see if the notochords would make mesenchyme because in vivo they don't. But when they were submerged in the collagen gel they did. He went around showing his pictures to people and no one would believe him. I remember saying to him, 'why don't you repeat' that. And he did and it really worked. This aroused my interest and his too and he went on to look at lens, cornea, different collagen types etc. But I got going again on EMT because of Gary Greenburg. I couldn't get it out of my mind. It was just remarkable to see these epithelia transform into mesenchyme when they were suspended in the collagen gels (Greenburg and Hay), 1982).

When a dental research fellow, Jim Fitchett, joined the lab about this time, we decided to look at the possibility that EMT removed the palatal seam that forms when the opposed shelves fuse. We proved it by TEM. In the palate, EMT is triggered by TGF $\beta 3$ and organ cultures provide an excellent in vivo type environment to study EMT signaling, which is primarily by LEF-1. We have now shown that TGF $\beta 3$ upregulates LEF1, a gene Kwonseop Kim in our lab proved is the major inducer of EMT. To our amazement, Smad2 stimulated by TGF $\beta 3$ will activate transcription of LEF1 in place of $\beta$-catenin. This is an exciting mechanism we are totally absorbed in exploring further (Nawshad and Hay, 2003).

\section{Who was Louise Foote Pfeiffer and how did that Profes- sorship influence your career?}

She was the wife of a very wealthy man named Gustavus Pfeiffer who set up a series of Professorships at Harvard. They set up one in Embryology which they gave to Anatomy, there was another in Pathology and there was one in Neurobiology. When I was awarded the named chair in Embryology, I was an Associate Professor and given tenure. That part was quite important to me. Fawcett was a fairly taciturn person. He wouldn't just have a little conversation with you about your future in the department. I wanted to know. At that time Jim Ebert had offered me a position at the Carnegie Institute of Embryology as a full member. He wanted very much to bring in EM. I was also collaborating with Don Brown and John Gurdon. In fact I have a paper on the ultrastructure of the nucleolus with John.

I made an appointment with Fawcett and took a big swallow of water and went in and said l'd had an offer from Jim Ebert to join
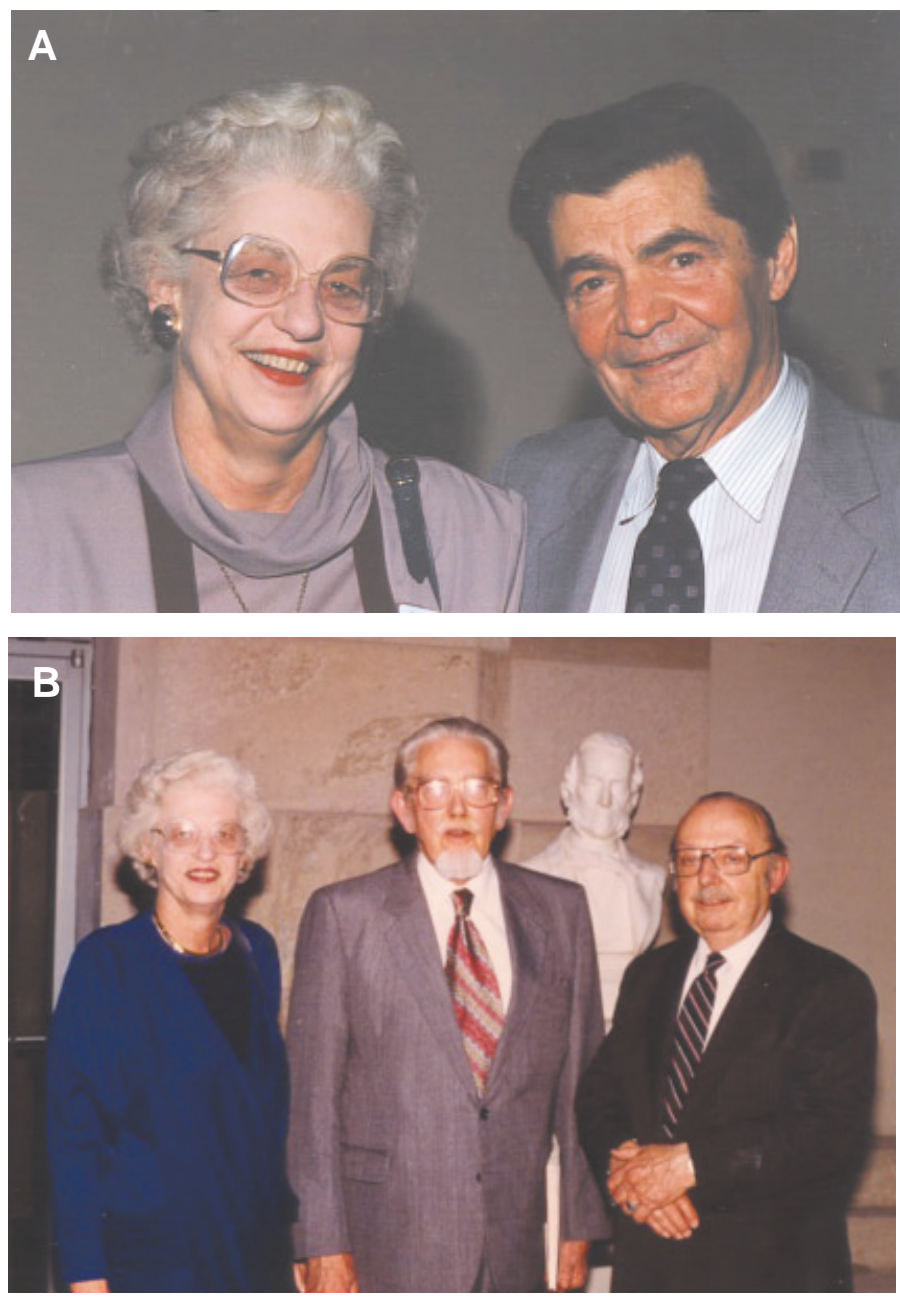

Fig. 5. Dr. Hay attending the first Fawcett Lecture. (A) With George Palade. (B) Dr. Hay with Fawcett (middle) and Porter (right). 
the Carnegie and I really needed to know what my future in the department was going to be. You get to a point where you want to know where you stand. It was really difficult for me. It came as a surprise to learn not only did I have tenure, but also a named chair, with Embryology in the title.

Don't misunderstand me, I owe everything that I am to Fawcett because coming up with him from Cornell to Harvard and then continuing to do really good TEM was splendid for my career. In subsequent years when the whole department would go to meetings as a group and we'd get up and particularly Fawcett would and announce the latest thing that had been found in the nucleus or what have you with electron microscopy. You were where the action was then. That enthusiasm I owe completely to Fawcett. As a result, I'm still working every year to set up an excellent Fawcett Lecture in Cell Biology as a tribute to him at Harvard. In the long run nearly everyone feels this way. He gave you so much that it was very easy to put up with the ambiguity. His friends and students raised a very good endowment for the Lecture. Palade gave the first lecture (Fig. 5A) attended by Porter (Fig. 5B) and many out of towners (Fig. 4C).

\section{Summary}

This interview is a distillation of 43 years of conversations beginning in 1961 and extending to the present. While there were, indeed, recent taped interviews to focus this article, the ground covered on the tapes repeats and expands prior discussions. I have been taught by, learned from, guided and assisted in my early years as a medical student at Harvard Medical School by Betty Hay, including a year's leave of absence to explore the morphogenesis of the primary mesenchmye and epithelial somite and then become a colleague and competitor. In the spirit of the interview series in The International Journal of Developmental Biology, I owe much to my developmental biology mentors, beginning with Betty Hay and Jean-Paul Revel at Harvard Medical School, Chris Coulombre at the National Institutes of Health and Jerry Gross at the Massachusetts General Hospital.

\section{References}

FISCHMAN, D.A. and E.D. HAY. (1962). The origin of osteoclasts from mononuclear leucocytes in regenerating newt limbs. Anat. Rec. 143:329-338.

GREENBURG, G. and E.D. HAY. (1982). Epithelia suspended in collagen gels lose polarity and express characteristics of migrating mesenchymal cells. J. Cell Biol. 95:333-339.

HAY, E.D. (1962). Cytological studies of dedifferentiation and differentiation in regenerating amphibian limbs. In: Regeneration, D. RUDNICK, ed. The Ronald Press Co., New York, pp. 177-210.

HAY, E.D. and J.-P. REVEL. (1963). Autoradiographic studies of the origin of the basement lamella in regenerating salamander limbs. Dev. Biol. 7:152-168.

HAY, E.D. (1980). Development of the vertebrate cornea. Int. Rev. Cytol. 63:263322.

HAY, E.D. and D.A. FISCHMAN. (1961). Origin of the blastema in regenerating limbs of the newt Triturus viridescens. An autoradiographic study using tritiated thymidine to follow cell proliferation and migration. Dev. Biol. 3:26-59..

MEIER, S. and E.D. HAY. (1974). Control of corneal differentiation by extracellular materials. Collagen as a promoter and stabilizer of epithelial stroma production. Dev. Biol. 38:249-270.

NAWSHAD A and E.D. HAY. (2003). TGFbeta3 signaling activates transcription of the LEF1 gene to induce epithelial mesenchymal transformation during mouse palate development. J Cell Biol. 163(6):1291-301.

SUGRUE, S.P and E.D. HAY. (1986). The identification of extracellular matrix (ECM) binding sites on the basal surface of embryonic corneal epithelium and the effect of ECM binding on collagen production. J. Cel/ Biol. 102:1907 1916.

TRELSTAD, R.L., E.D. HAY and J.-P. REVEL. (1967). Cell contact during early morphogenesis in the chick embryo. Dev.Biol. 16:78-106. 